\title{
A METÁFORA COMO RECURSO EXPRESSIVO NA SONATA № 1 PARA VIOLINO E PIANO DE ALMEIDA PRADO
}

\section{METAPHOR AS AN EXPRESSIVE RESOURCE IN ALMEIDA PRADO'S SONATA NO. I FOR VIOLIN AND PIANO}

\author{
Luciana Caixeta \\ Escola de Música de Brasilia \\ lucianacaixeta@hotmail.com \\ Fernando Corvisier \\ Universidade de São Paulo \\ corvisier@usp.br
}

\section{Resumo}

Este artigo aborda o processo de elaboração de uma interpretação da Sonata $n^{\circ}$ I para violino e piano de Almeida Prado, numa abordagem que procura esclarecer questões relacionadas à performance do ponto de vista do intérprete e da sua prática performática. A partir do modelo operativo proposto por Correia (2007), investigou-se a escrita da parte do violino e suas implicações interpretativas, assim como o uso da metáfora enquanto recurso expressivo. Elementos recorrentes na parte do violino indicam uma preocupação do compositor em explorar efeitos de ressonância e o aspecto lírico do instrumento. Seu uso particular de indicações metafóricas aparece intrínseco ao gesto musical, revelando uma especificidade que transcende a notação musical.

Palavras-chave: Almeida Prado; Práticas interpretativas; Música brasileira; Música de câmara. 


\begin{abstract}
This article discusses the process of elaborating an interpretation of the Sonata $n^{\circ}$ I for violin and piano by Almeida Prado, in an approach that seeks to clarify questions related to performance from the interpreter's point of view. Considering the operative model proposed by Correia (2007), this work investigates the particularities of the composer's writing of the violin part and their interpretative implications, as well as the use of metaphor as an expressive resource both by the composer and by the interpreter. Recurring elements in these works indicate a concern of the composer in exploring effects of resonance and the singing quality of the violin. His particular use of metaphorical cues appears intrinsic to the musical gesture, revealing a specificity that transcends musical notation.
\end{abstract}

Keywords: Almeida Prado; performance practice; Brazilian music; chamber music.

\title{
Introdução
}

José Antônio Rezende de Almeida Prado (1943-2010) é um compositor de indiscutível relevância para a música brasileira. Embora tenha escrito uma extensa obra dedicada ao piano - através da qual desenvolveu sua linguagem musical própria por meio da exploração das ressonâncias do instrumento, do uso racional da série harmônica e da sobreposição de ritmos, acordes e melodias, que utiliza para criar atmosferas sonoras diversas (CORVISIER, 2000; FERRAZ, 2009) - sua produção camerística é bastante considerável, "comparável apenas àquela de Osvaldo Lacerda" (RODRICUES, 2006, p. 43) e constituem um "repertório merecedor de nossa cuidadosa atenção" (BARANCOSKI, 2005, p. 18).

Dentre as mais variadas formações instrumentais, nota-se uma preferência pelo piano e instrumentos de cordas (BARANCOSKI, 2005). Além de O Livro Mágico de Xangô (1985) para violino e violoncelo, escreveu dois trios para violino, violoncelo e piano - o Trio de Fontainebleau ( 1971 ) e o Trio Marítimo (1985) -, uma Sonata para viola e piano (1983), uma Sonata para violoncelo e piano (2003) e quatro sonatas para violino e piano, formação a que também dedicou várias obras curtas. 
A primeira sonata para violino e piano "é a obra de maior dimensão da produção de Almeida Prado para violino e piano" (RODRICUES, 2006, p. 44) e apresenta uma variedade de recursos no tratamento do material sonoro. Dedicada ao virtuose Natan Schwartzman, é, dentre as quatro sonatas, a que apresenta uma linguagem mais ousada e experimental. Originalmente, constavam apenas três movimentos, tendo sido o último acrescentado a pedido do violinista. Foi estreada por Schwartzman e pelo próprio Almeida Prado em Campinas, no mesmo ano de sua composição. Todavia, só seria gravada em 2006 pela violinista Constança de Almeida Prado e pelo pianista Achile Picchi, juntamente com outras obras para violino e piano (ALMEIDA PRADO, 2006)ํ.

Considerando a linguagem e a poiésis do compositor, ao investigar - processo de elaboração interpretativa da Sonata $n^{\circ}$ I para violino e piano, procura-se esclarecer: quais são os recursos específicos do violino utilizados pelo compositor nessas obras? De que maneira esses recursos são empregados na elaboração do discurso musical e quais seriam suas implicações para a prática interpretativa?

Devemos considerar, também, que Almeida Prado utiliza-se de indicações metafóricas não convencionais que transcendem a notação musical tradicional. Nas partituras das Sonatas para violino e piano, encontramos indicações tais como "Granítico", "Luminoso" e "Como um cristal transparente". Busca-se, portanto, compreender essa maneira bastante particular de utilizar a metáfora como recurso expressivo e como ela pode ser traduzida em gestos ${ }^{2}$ que produzem o resultado sonoro na performance dessas obras.

I Neste CD, foram gravadas as Sonatas n० 1, 2 e 3, Sonatina, Diálogo, Cantiga de Amizade e Balada "B'nai B'rith" (ALMEIDA PRADO, 2006).

2 Albert Nieto explica que o gesto expressivo é uma das manifestações do intérprete que poderíamos englobar na "linguagem do corpo", junto com outros sinais visuais como os olhares ou a forma de se portar no palco que ajudam o público a perceber as emoçōes que 0 intérprete comunica no momento da performance musical (NIETO, 20l6, p. 20). 0 autor ressalta que o gesto expressivo aparece completamente integrado aos movimentos próprios da produção sonora, através dos quais são observados os parâmetros de articulação, timbre, dinâmica e agógica - que constituem o "gesto técnico" (NIETO, 2016 , p. 20). 


\section{Considerações sobre a pesquisa em performance}

estudo da performance tem ocupado cada vez mais espaço nas pesquisas da área musical. Compreender o trabalho do performer torna-se uma questão central nos artigos que abordam as práticas interpretativas (BORÉM; RAY, 2012; CORREIA, 2007; CORVISIER, 2017; DOĞANTAN-DACK, 2011; NIETO, 2016; RINK, 2018). Se, há algumas décadas, a reflexão sobre a música permanecia primordialmente focada no estudo da partitura e encontrava na análise estrutural sua principal ferramenta de investigação, atualmente, percebe-se uma clara tendência em pesquisar a música a partir da sua prática, do fazer musical, ou seja, da performance propriamente dita (COOK, 2013; DOČANTAN-DACK, 2015). Neste cenário, o performer ocupa uma posição primordial e assume, ao mesmo tempo, o papel de pesquisador, ao investigar sua própria prática (DAVIDSON, 2015).

Interessa investigar:

o processo de tomada de decisões na criação de uma interpretação [...], o modo de saber que influencia [...] as escolhas dos intérpretes. Posta nestes termos, a questão da interpretação musical é automaticamente desviada de questões filosóficas, analíticas ou estéticas e centrada no trabalho dos intérpretes, na prática performativa onde o fazer música se substitui [...] ao discurso musicológico mais tradicional sobre música (CORREIA, 2007, p. 63, grifo do autor).

Nesse sentido, Jorge Correia (2007) propõe um modelo operativo para o processo de elaboração da performance. Em um primeiro momento, o autor sugere a contextualização da obra em sua relação com o conhecimento acumulado do intérprete e sua compreensão do texto musical num âmbito geral; o intérprete, então, deve associar conteúdos emocionais a cada frase da obra, dando-lhes significado, por meio de metáforas. Em seguida, há a prática da realização sonora desses conteúdos através do estudo no instrumento. Por fim, a fruição 
do desvelamento do discurso musical através das da performance, que seria o devir ${ }^{3}$.

\section{A Metáfora}

Segundo Bittencourt (2008, p. 80), no "trabalho interpretativo - a elaboração que transforma as instruções mudas da partitura em suas realizações sonoras - nós [os performers] o escutamos já murmurando em metáforas". Assim, é através da metáfora que "saímos do campo do puro sonoro musical, para mergulhar onde ele se mistura ao verbal" (BITTENCOURT, 2008, p. 80). A metáfora torna-se, portanto, uma ponte entre o não-verbal da "música viva", aquela que os músicos produzem através da performance, e o discurso verbal acerca dos eventos musicais (BITTENCOURT, 2008, p. 82)4.

Cox (20 I 1), Leech-Wilkinson e Prior (20 | 4) explicam que a metáfora provoca uma reação física que, ainda que seja imperceptível ao sujeito, ativa conteúdos emocionais a ela associados, dando-the significado. Essa sensação provocada pela metáfora "dirige as ações motoras necessárias para [O performer] produzir os sons" (LEECH-UILKINSON; PRIOR, $20 \mid 4$, p. 36, tradução nossa) ${ }^{5}$ e, ao modificar a qualidade do movimento físico empregado ao tocar, influi no resultado sonoro por ele produzido. Assim, a metáfora funciona como um atalho: ao invés de se decompor em um detalhado passo-a-passo todas as ações envolvidas no gesto para executar determinado som de uma maneira específica, a metáfora traduz o conceito sonoro em execução, ou seja, em movimento, de forma direta.

Indicações metafóricas como "granítico", "iluminado", "como um cristal transparente" são "um apelo à fantasia, à escuta e à busca pelo intérprete de toques e sonoridades particulares" (CANDELMAN; COHEN, 2006 , p. 19). A metáfora torna-se, portanto, um elemento fundamental

3 Segundo o dicionário, devir significa tanto o processo contínuo de transformação pelo qual passam os seres quanto sua capacidade de criar e transformar (FERREIRA, 1986). Assim, através da performance a obra passa a existir, não como um objeto estático e acabado, mas sujeito a constantes transformações e aberto a reconstruções.

4 Bittencourt (2008) discute que mesmo indicações convencionais como Allegro e Moderato são utilizadas metaforicamente, pois expressam estados de ânimo e o som em si mesmo não está imbuido de tais qualidades.

5 Versão original: "(...) drive the motor actions required to produce the sounds".

\section{1}

REV. TULHA, RIBEIRÃO PRETO, v. 5, n. 1, pp. 87-118, jan.-jun. 2019 
para a criação sonora e para a qualidade do gesto físico gerador de som através do instrumento. Nas palavras do próprio compositor, "é do pictórico que eu parto para chegar ao abstrato e esses títulos coloridos, poéticos são guias" tanto para o compositor quanto para o intérprete (MARIZ, 1994, p. 388).

\section{Movimento I: Granítico}

Sob as indicações de dinâmica fortíssimo e de caráter Granítico 6 e intenso!, o violino apresenta o primeiro fragmento temático com notas acentuadas no registro grave do instrumento, de maneira bastante intensa e dramática (Figura 1). A relação com o granito, material duro, frio, denso, sólido e pesado implica numa execução que traduza sonoramente essas características. Procura-se uma sonoridade intensa, incisiva, que enfatize o ataque pronunciado de cada nota e que permita que a corda vibre com a maior amplitude possivel. Uma experimentação sonora possivel seria tocar todas as notas do primeiro compasso com arco para baixo, retomando o arco próximo ao talão e executando cada nota com bastante peso do braço. Mesmo que o intérprete escolha uma arcada diferente para a performance, a experiência física e sonora deste exercício torna-se uma referência desse efeito intenso, forte e denso (Figura 1).

No segundo compasso, o violino ataca a nota Si com acento e, em seguida, realiza um crescendo. Tal efeito seria impossivel de se realizar no piano, uma vez que, neste instrumento, o som começa a se extinguir imediatamente após o ataque. Sua execução no violino é bastante natural: é possivel executar o acento iniciando-se com o arco bem próximo ao talão, utilizar bastante peso e velocidade para soar $\mathrm{O}$ acento $e$ imediatamente desacelerar $\mathrm{o}$ arco, fazendo decair a intensidade sonora e, em seguida, aumentar gradualmente o peso e a velocidade do arco, ampliando o volume sonoro. É um claro exemplo da utilização de um recurso específico do violino. Para criar um efeito semelhante no piano, Almeida Prado utiliza o acúmulo de ressonâncias de arpejos rápidos, já que, nesse instrumento, não seria possivel realizar o crescendo numa nota longa (Figura 1).

6 Segundo o dicionário, granítico significa “1. Da natureza do granito; granitoso. 2. Muitíssimo consistente; duríssimo” (FERREIRA, 1986, p. 864).

\section{2}




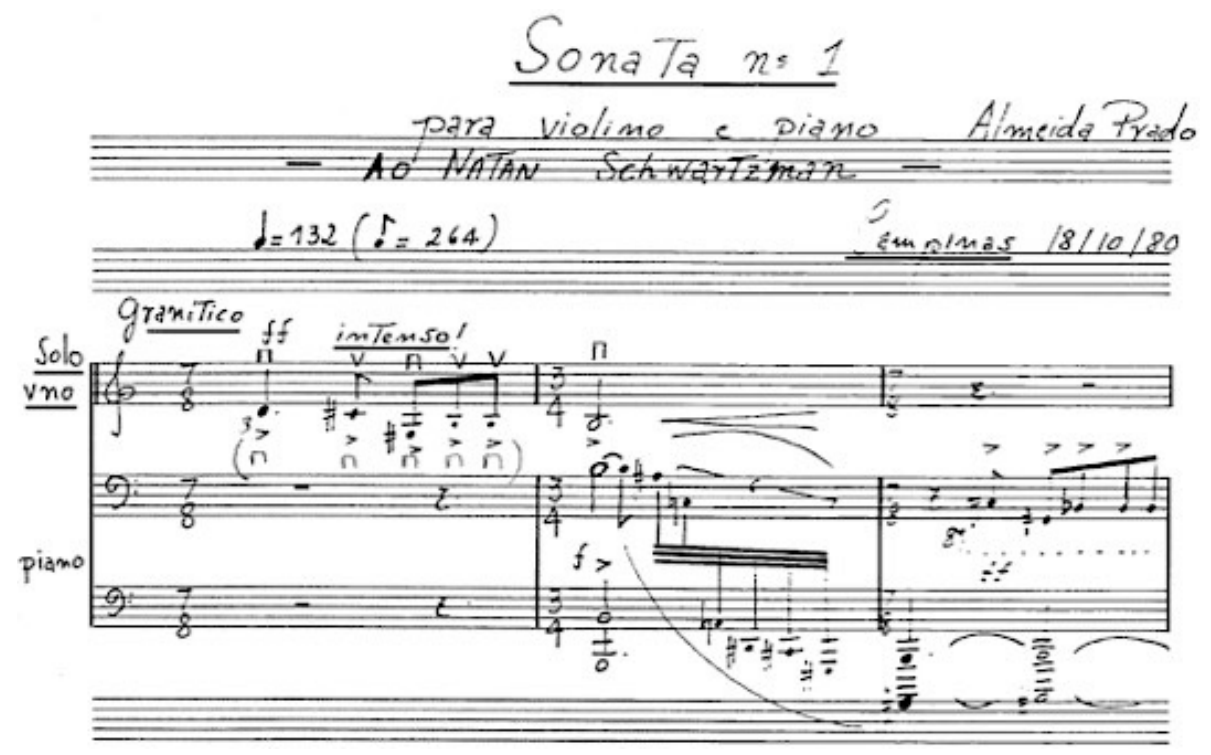

Figura I - Sonata $n^{\circ}$ | para violino e piano, mov. l, c. I-3

Interessante notar o efeito da apogiatura de quatro notas na parte do violino no compasso 9 (Figura 2). Ao tocar as quatro cordas do violino o mais rapidamente possível e deixando-as soar enquanto toca a semínima pontuada (Ré), cria-se um efeito semelhante ao da ressonância de arpejos tocados pelo piano, como acontece no compasso seguinte (Figura 2).

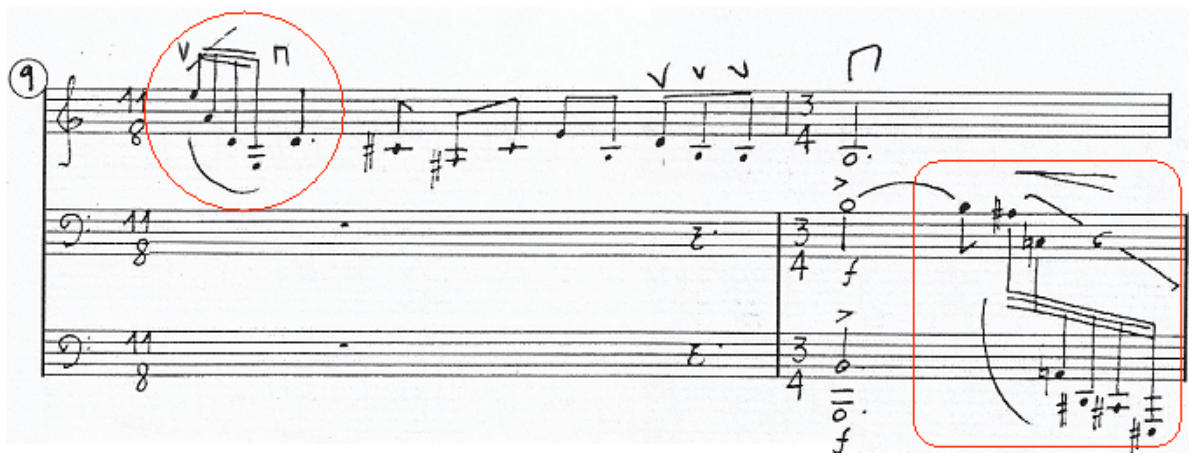

Figura 2 - Sonata $n^{\circ}$ I para violino e piano, mov. I, c. 9- 10 
$\bigcirc$ primeiro tema é apresentado por meio de gesto responsorial entre o violino e o piano (c. 1-15). A partir do compasso 16, inicia-se um período de maior estabilidade métrica e de maior desenvolvimento melódico na parte do violino, sobreposta ao acompanhamento do piano. A tensão criada pelo ritmo sincopado do piano e pelo uso do registro cada vez mais agudo de ambos os instrumentos é intensificada pelo crescendo e pelo trêmulo na parte da mão direita do piano (c. 23). A repetição da figuração de semicolcheias na parte da mão esquerda do piano introduz a ideia do ostinato, que será desenvolvida na próxima seção. $\bigcirc$ discurso musical é subitamente suspenso por uma cesura, que permite dissipar o acúmulo de ressonâncias e prepara a entrada do segundo tema no compasso 24 (Figura 3).

A indicação "Como um cristal transparente" acompanha uma mudança súbita de dinâmica (pp), de andamento $(q=120)$ e de caráter. Requer uma sonoridade tênue, que transmita a delicadeza e a fragilidade descrita pelas palavras do compositor - aspectos completamente opostos à solidez e à vigorosidade do primeiro tema. $\mathrm{Na}$ parte do violino, esse contraste pode ser evidenciado ao tocar o segundo tema com o arco leve, próximo ao espelho, com pouca velocidade, inclinado para a esquerda de maneira que somente uma parte da crina toque as cordas, com um vibrato estreito e discreto. A utilização de harmônicos artificiais no final do tema torna o aspecto sonoro ainda mais vítreo: composto por pouquíssimos sons parciais, esses harmônicos produzem uma sonoridade escassa, quase transparente, traduzindo em som a indicação metafórica do compositor.

ostinato tocado pelo piano apresenta uma sequência de quatorze notas (RODRICUES, 2006, p. 45), constituida de uma série dodecafônica à qual é acrescentado um gesto anacrústico ascendente de duas notas que funciona como elemento de ligação que impulsiona o reinício da série (Figura 3). Essa liberdade na abordagem da técnica serial demonstra uma preocupação muito maior com o gesto musical e com a direcionalidade da frase do que com as regras ou convenções de um sistema composicional.

A escrita polimétrica evidencia o elemento serial da parte do piano como unidade sonora estruturante desta seção, disposta em um único compasso de 14/8, sobre a qual a linha do violino, em 4/4, parece flutuar livremente (Figura 3). A ausência de ligaduras de frase no gesto distendido e suspensivo do violino, quando somada serialismo e

\section{4}

REV. TULHA, RIBEIRÃO PRETO, v. 5, n. 1, pp. 87-118, jan.-jun. 2019 
à regularidade rítmica do acompanhamento, revela o caráter estático e remete à natureza inerte, vitrea do cristal a que se refere a indicação textual deste tema 7 .

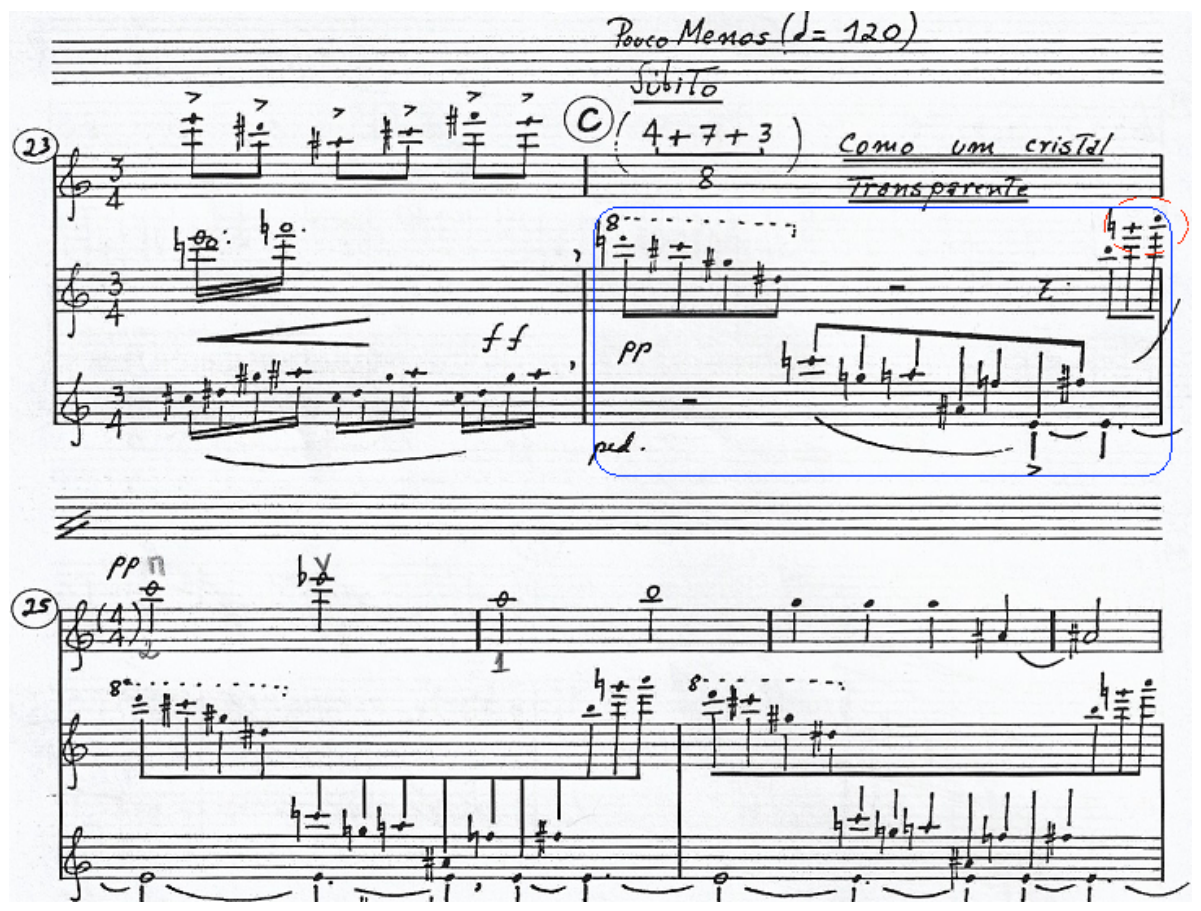

Figura 3 - Sonata $\mathrm{n}^{\circ}$ I para violino e piano, mov. I, c. 23-28

O reinício da frase do violino coincide com a retomada do ostinato (c. 29) e, embora apresente as mesmas notas, sua ordem é permutada, numa discreta variação do material temático. $\bigcirc$ ostinato do piano é, então, reduzido a uma figuração de oito notas e a ambiguidade métrica é resolvida num compasso 4/4. Um decrescendo de pp para ppp e a aumentação das figuras rítmicas na parte do violino, que cria o efeito de um rallentando, concluem a exposição.

7 Na gravação de Prado/Picchi, este ostinato serial do piano soa como o tilintar calmo de um móbile de cristais (ALMEIDA PRADO, 2006). $\bigcirc$ andamento em torno de $\cdot=100$ enfatiza o aspecto estático e realça o contraste com o bloco temático anterior. 
desenvolvimento inicia-se no compasso 39 com uma intervenção súbita do piano, que retoma fragmentos do primeiro tema e seu caráter dramático e intenso. $\bigcirc$ violino elabora o material temático num gesto distendido, predominantemente melódico. $\bigcirc$ discurso volta a ser responsorial e a própria instrumentação se torna um elemento de polarização.

As cordas duplas na parte do violino exploram a sonoridade aberta das cordas soltas e acentuam a divisão métrica do 7/8. $\bigcirc$ uso de intervalos com intensa dissonância, como a $2^{a}$ menor, provoca 0 choque entre os harmônicos e amplia a potência sonora do instrumento no seu diálogo com o piano. A repetição insistente dos acordes de quatro notas no compasso 52 (Figura 4) parece ser um ponto incisivo no diálogo entre os instrumentos e interrompe a sequência métrica anterior (5/8). Executar esses acordes com arcadas para baixo, retomando o arco, mantém a intensidade sonora ao longo dos cinco acordes e faz soar as quatro notas quase simultaneamente, semelhante à maneira da execução no piano. $\bigcirc$ dedilhado sugerido é mais cômodo por evitar extensões e respeita a ordem em que as notas foram escritas - da esquerda para a direita - ao tocar a nota Mi na corda mais grave, seguida pela corda Ré solta.

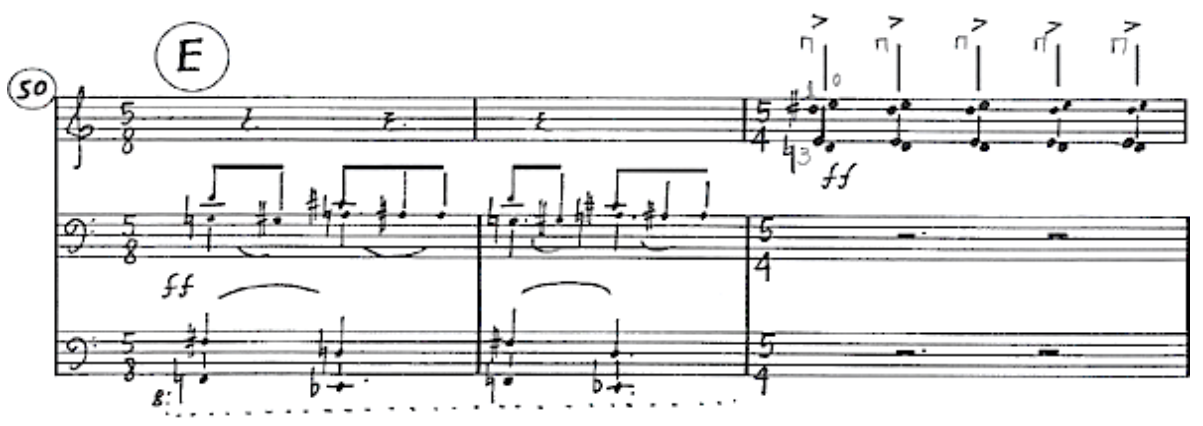

Figura 4 - Sonata $n^{\circ}$ I para violino e piano, mov. I, c. 50-52

piano responde tocando acordes que exploram os registros extremo agudo e grave do instrumento como meio de ampliar suas ressonâncias. Em seguida, o material do segundo bloco temático em pianíssimo é interpolado ao discurso musical como elemento de contraste. $\bigcirc$ violino assume o ostinato dodecafônico, outrora apresentado pelo 
piano. Para imitar a sonoridade percussiva do piano, busca-se uma articulação intermediária entre o legato e o portato, na metade superior do arco, num movimento pendular uniforme e constante do antebraço, quase senza vibrato.

Um fragmento do primeiro tema aparece invertido no violino, em cordas múltiplas, com grandes saltos melódicos, num gesto virtuosístico que remete a uma cadência de um concerto (Figura 5). A expansão sonora também é refletida nos movimentos do arco, que toca acordes de três notas com acentos, e da mão esquerda, ao se deslocar rapidamente entre o registro grave e o extremo agudo no acorde de quatro sons do compasso 64 (Figura 5). Sugere-se que as três semicolcheias que compõem a anacruse para o compasso seguinte sejam executadas ligadas, unindo-as num gesto descendente impulsionado para o próximo tempo forte.

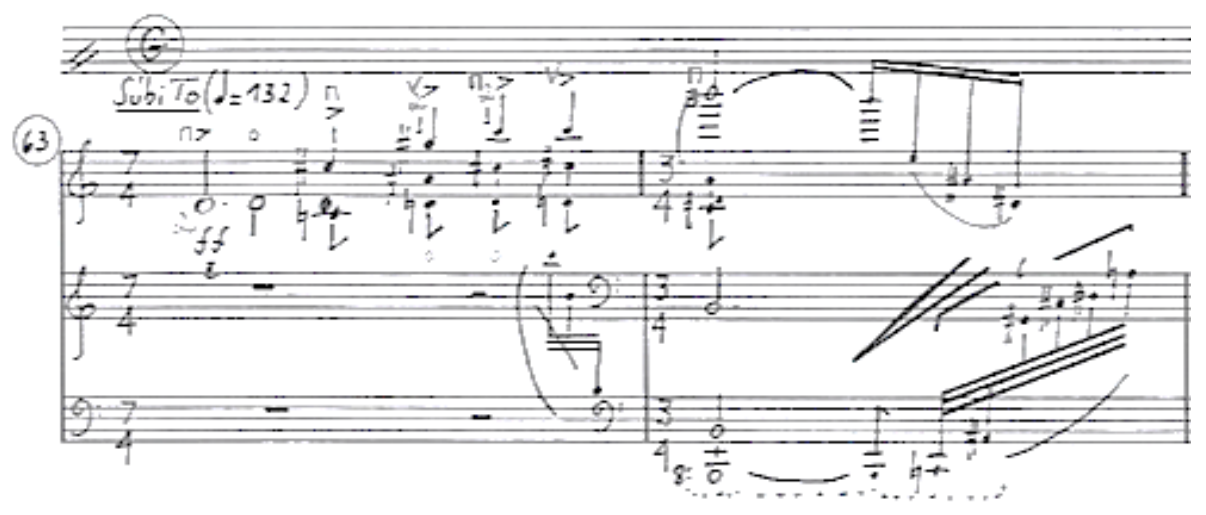

Figura 5 - Sonata $n^{\circ} 1$ para violino e piano, mov. l, c. 63-64

Em seguida, materiais de ambos os temas são retrabalhados simultaneamente: na parte do piano, uma variação do ostinato dodecafônico se sobrepõe à parte do violino, que desenvolve, com maior variedade melódica, gestos rítmicos do primeiro tema (c. 65-89). Os instrumentos se alternam na divisão binária e ternária do pulso, numa escrita polirrítmica que acrescenta movimentação e densidade à textura musical (Figura 6). A organização e a clareza da execução dependem da correta acentuação das figuras rítmicas, ou seja, é preciso evidenciar os tempos fortes de cada compasso de acordo com a subdivisão binária ou ternária explicitada pela notação. 


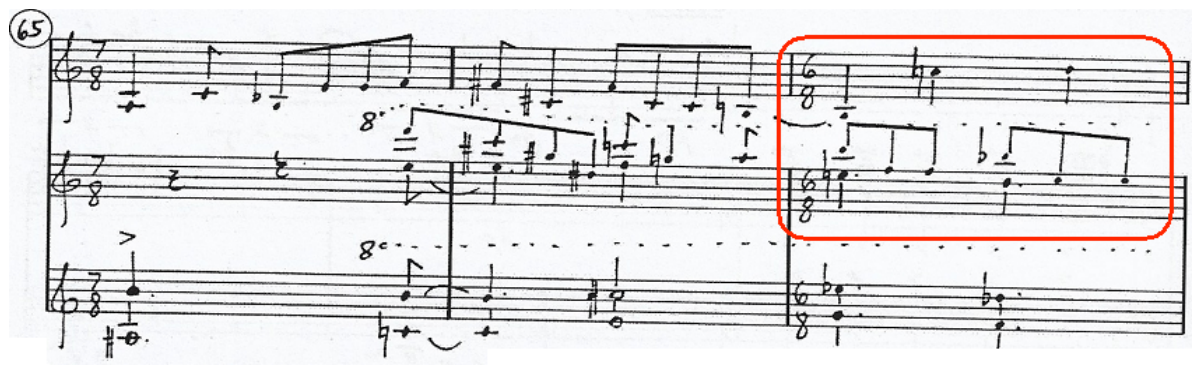

Figura 6 - Sonata $n^{\circ}$ I para violino e piano, mov. l, c. 65-67

Aos poucos, a linha do violino se torna menos rítmica e mais melódica. Nessa transição, a articulação se torna cada vez mais legato e a métrica é diluída pelo uso de quiálteras de cinco notas na parte do piano contra quiálteras de três na parte do violino. Apesar de não estar indicado na partitura, a dinâmica pode acompanhar o contorno da linha melódica, criando direcionalidade na execução da frase.

Uma figuração arpejada nas quatro cordas do violino amplia a movimentação rítmica e a intensidade sonora, que culmina no clímax do movimento (c. 90). As notas longas sustentadas pelo violino apresentam o contorno melódico do motivo inicial da obra, com o caráter sostenuto (Figura 7). A polirritmia do acompanhamento arpejado do piano e das quiálteras do violino pode ser organizada pela divisão do compasso quaternário em dois grandes pulsos. Assim, os arpejos podem ser executados em dois impulsos, como sugerido pelas ligaduras - duas por compasso - indicadas na partitura (Figura 7). 


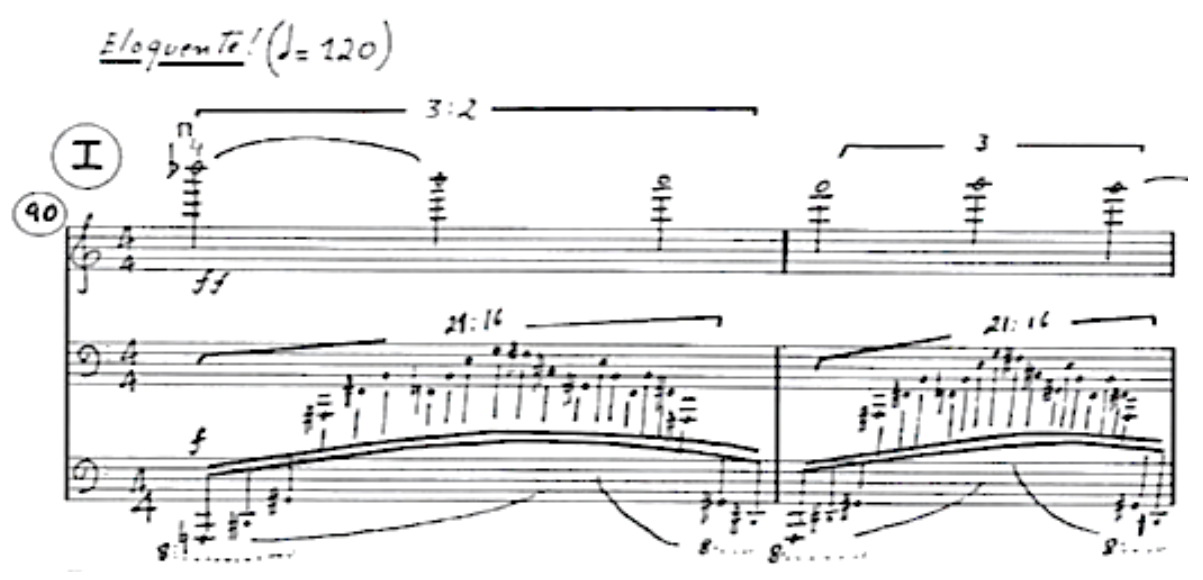

Figura 7 - Sonata $n^{\circ} \mid$ para violino e piano, mov. I, c.90-93

$\mathrm{Na}$ recapitulação, o piano reapresenta $\mathrm{O}$ primeiro tema em oitavas, expande a sonoridade e cria um efeito polifônico. No violino, o uso de cordas duplas, mais uma vez, recorre extensivamente às cordas soltas do instrumento, o que amplia as ressonâncias e adensa a textura. $\bigcirc$ gesto arpejado do violino remete ao virtuosismo improvisatório de uma cadência de concerto (Figura 8).

A alternância entre subdivisões binárias e ternárias do pulso é bastante clara na escrita do compositor e dela depende a correta acentuação e direção dos motivos e frases musicais. A gradativa redução métrica de 9/8 para 2/8 (c. 114-124) condensa o material temático enquanto a intensidade sonora é ampliada através de um crescendo até fortíssimo. Com a chegada do segundo tema no compasso 125, em pianíssimo, o ostinato dodecafônico reaparece na parte do violino com trêmulo sul ponticello. A mudança súbita de sonoridade entre os diferentes materiais temáticos acontece ao mover o ponto de contato do arco para a região próxima ao cavalete para executar a indicação sul ponticello e pela movimentação rápida do arco no trêmulo, criando uma sonoridade esparsa e remota, como se a música fosse, aos poucos, desaparecendo, sugerindo a conclusão da narrativa musical. 


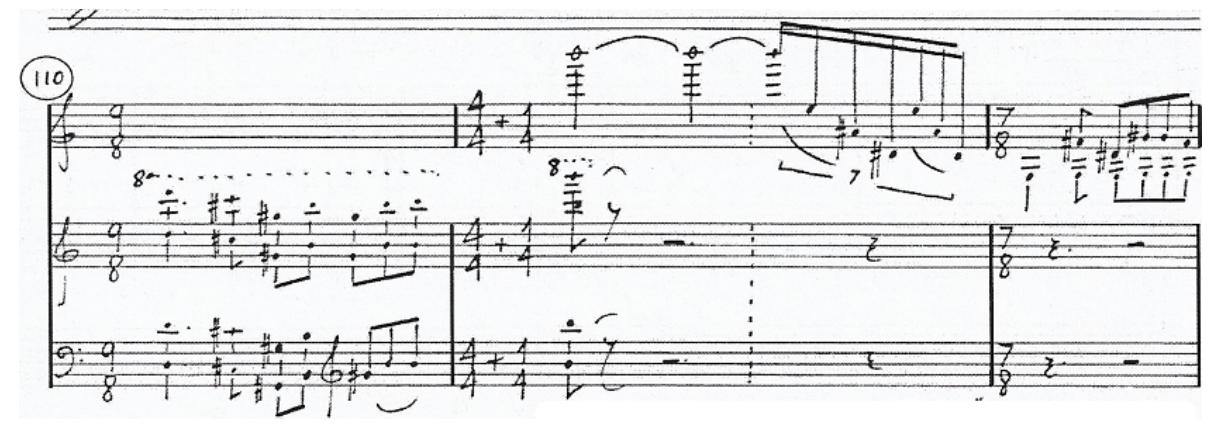

Figura 8 - Sonata $\mathrm{n}^{\circ}$ | para violino e piano, mov. l, c. $110-112$

movimento termina com uma coda (c. 141 -158). A partir do cluster do piano, o primeiro tema surge com ritmo tercinado na parte do violino, sobreposto à divisão binária da parte do piano. $\bigcirc$ desenho melódico, ora ascendente, ora descendente, indica uma possibilidade de condução do fraseado, dando maior intensidade sonora às notas mais agudas. Na repetição motívica quase hipnótica que encerra o movimento, um accelerando direciona a frase para o cluster final, seco, sem fermata.

$\bigcirc$ uso das descrições metafóricas neste movimento permite uma especificidade que vai além dos limites da notação musical. "A leitura atenciosa e criteriosa dessas indicações por si só já fornece muitas informações sobre como o compositor imaginou a interpretação" de cada seção da obra (ANSANTE, 2009, p. 10). O intérprete tem a função de traduzir sonoramente as indicações metafóricas do compositor, utilizando os recursos técnicos do instrumento na comunicação do conteúdo a que elas se referem.

Ao mesmo tempo, as metáforas indicativas de expressão estão diretamente relacionadas ao gesto físico empregado na performance da obra. No início deste movimento, ao tocar fortíssimo e com acentos na região grave do instrumento, aplicando o peso do braço sobre o arco, tornando-o pesado como granito, a metáfora aparece entrelaçada ao gesto performático. O texto musical e as indicações verbais se complementam, assim como o próprio ato de tocar e o contato físico com o instrumento ao executar a obra revela as ideias descritas pela metáfora. 
No primeiro tema, predomina o uso do registro grave do violino, cujos sons apresentam mais harmônicos parciais superiores e assim se tornam mais densos. As notas tocadas na corda mais grave do instrumento - que, por ser mais espessa, apresenta maior inércia - exige um contato intenso do arco com a corda. $\bigcirc$ uso do peso do braço sobre o arco de maneira que o som produzido seja vigoroso, cheio, encorpado e de um vibrato intenso e amplo traduzem sonoramente a metáfora que intitula este movimento.

Já no segundo tema, prevalece o uso do registro médio-agudo e notas tocadas na primeira e segunda cordas que, por serem mais finas, exigem menos esforço e menos peso do arco para soar, concretizando a ideia de transparência indicada pelo compositor. Sua concepção sonora encontra-se expressa não só nas metáforas inscritas na partitura, mas também na execução técnica do texto musical, sendo, ao mesmo tempo, percebida através do contato físico com o instrumento. A delicadeza e a fragilidade do "cristal transparente" se revelam no gesto de suspensão do peso do braço no arco, ao produzir um contato muito superficial da crina com a corda, assim como através do uso de um vibrato estreito e discreto que não perturbe a sutileza do momento.

A alternância entre materiais desses dois temas contrastantes propõe a principal questão técnico-interpretativa deste movimento: como executar a transição entre um e outro de forma súbita, imediata e efetiva. Enquanto o primeiro tema exige que intérprete solte o peso do braço sobre o arco para produzir intensidade e densidade sonora, além de utilizar um vibrato amplo e intenso, o segundo tema demanda alívio do peso do arco na corda, pouca velocidade de arco, ponto de contato do arco com a corda mais próximo ao espelho e um vibrato com menor amplitude, às vezes quase inexistente, transmitindo o caráter misterioso e suspenso da parte do violino. Aqui, é importante tornar as trocas de arco imperceptíveis, de maneira que não haja interrupção do som ao criar uma névoa contínua (Figura 3).

A escrita de Almeida Prado não é prescritiva: há relativamente poucas indicações de dinâmica e de articulação. Por exemplo, após a indicação fortíssimo no compasso 63 não está especificado como se deve abrir espaço sonoro para construir intensidade e momento para chegar no ápice sonoro deste movimento, no compasso 90. Portanto, cabe ao intérprete identificar as possibilidades e definir como executar essas nuances de modo que faça sentido no contexto sonoro da obra.

\section{1}


Uma opção é seguir o contorno da linha melódica, fazendo pequenas inflexões de dinâmica que direcionem a frase adiante, além de iniciar a sequência de arpejos (c. 86-89) com uma sonoridade menos intensa e realizar um crescendo que culmine no fortíssimo do compasso 90.

As subdivisões irregulares do pulso se mostram como uma maneira de viabilizar o registro do som imaginado dentro das restrições da notação musical convencional. A complexidade rítmica aparente nas polirritmias permite a fluidez do ritmo, criando um gesto contínuo que não é limitado pela métrica e que gera blocos sonoros complexos, percebidos como paisagens sonoras. E é através da sucessão dessas paisagens que o compositor desvela seu discurso musical.

\section{Movimento II: Contínuo, fantástico}

Traduzir sonoramente a indicação "Com atmosfera irreal!" através da sucessão de diversos efeitos sonoros alternados entre o piano e o violino, num revezamento contínuo de colorações, parece ser o grande desafio da performance deste movimento. A repetição hipnótica de ostinatos cria uma textura minimalista, na qual, muito mais do que a destreza técnica ou a precisão rítmica na execução dos diversos trinados, figurações rápidas, harmônicos, importa a cor, o timbre e a continuidade do discurso musical entre os instrumentos.

gesto inicial deste movimento, em dinâmica piano, parte do inexistente, de uma atmosfera irreal - conforme a indicação do compositor. Por isso, é importante observar, durante a performance, que a duração do intervalo entre o primeiro e o segundo movimento seja suficiente para poder extinguir completamente o acúmulo das ressonâncias.

O trilo entre as notas Lá e Si bemol é imediatamente ampliado para uma figura de três, depois de quatro notas (Figura 9). No registro agudo do violino, essas notas soam nítidas e brilhantes quando executadas na corda Mi. A opção pelo de dilhado na $2^{\varrho}$ corda cria uma sonoridade mais opaca e misteriosa. Mudanças de arco imperceptiveis, ponto de contato próximo ao espelho, suspensão do peso do braço direito - como se o braço retirasse peso do arco, fazendo-o flutuar sobre a corda -, contribuem, assim como a leveza e agilidade dos dedos da mão esquerda, sem tensão ou esforço desnecessário, para a representação da paisagem onírica indicada pelo compositor. 


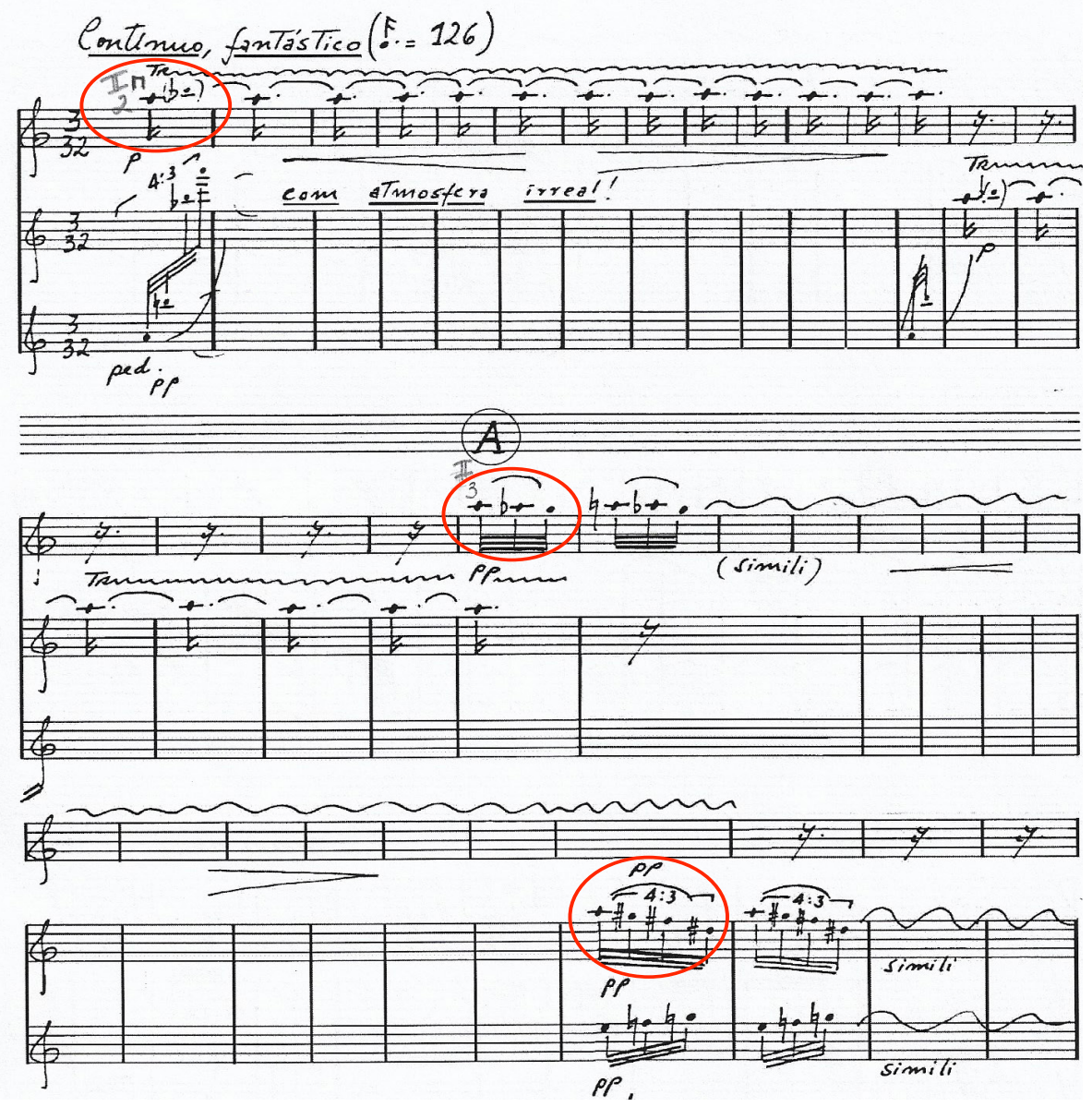

Figura 9 - Sonata $\mathrm{n}^{\circ}$ I para violino e piano, mov. II, [A]

trêmulo na região mais grave do violino e o uso de intervalos dissonantes como segundas maiores e menores em cordas duplas criam uma sonoridade tensa (Figura 10). Como a corda Ré solta tende a produzir um maior volume sonoro do que a corda presa, é preciso aplicar mais peso na corda mais grave para que as duas notas soem de 
maneira equilibrada. $\bigcirc$ arco precisa tocar duas cordas simultaneamente, além de mover-se continuamente próximo ao cavalete para executar o trêmulo em sul ponticello.

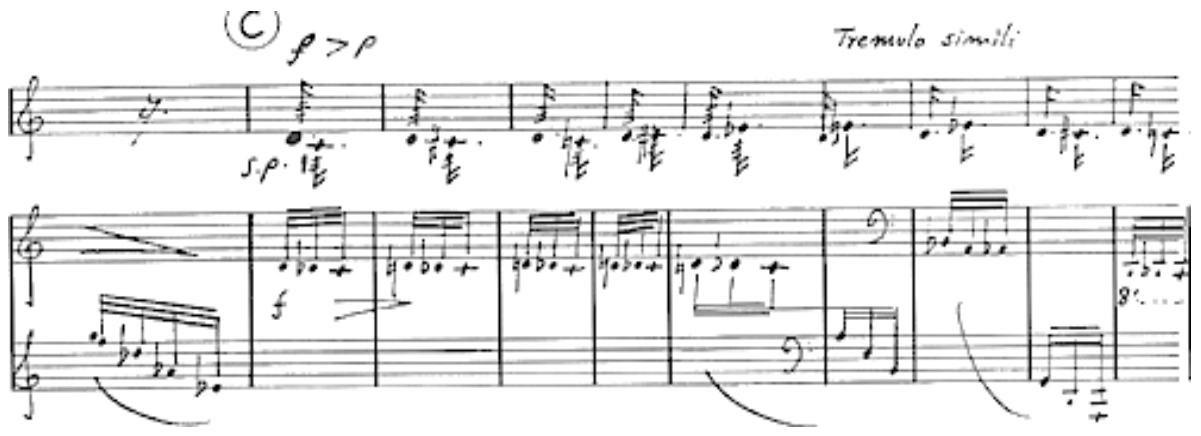

Figura 10 - Sonata no $\mid$ para violino e piano, mov. II: [C]

Os intervalos das cordas duplas são progressivamente ampliados. uso do registro cada vez mais agudo em ambos os instrumentos cria uma tensão crescente e chega ao clímax na letra de ensaio D. Apesar de não haver indicação escrita de crescendo, a projeção sonora aumenta com a mudança na tessitura. Em seguida, a narrativa musical descende em escalas fulgurantes no piano até a região mais grave do instrumento.

Um glissando em pizzicato no violino causa um efeito surpresa e impulsiona os arpejos agudíssimos do piano. Esses arpejos, de sonoridade brilhante e fulgaz, são imitados pelo violino com um gesto de harmônicos naturais rapidíssimos em cordas duplas, que soam como um assobio (Figura 11). A maior dificuldade técnica desse trecho é controlar o contato simultâneo do arco nas duas cordas e dos dedos da mão esquerda para produzir esses harmônicos. A maior distância entre as cordas nas posições mais agudas e mais próximas ao cavalete pode ser compensada pela colocação dos dedos numa posição mais horizontal, favorecendo seu contato com ambas as cordas. Apesar das alturas exatas dos harmônicos estarem escritas por extenso, a execução acontece num gesto natural de deslizar rapidamente os dedos sobre as cordas, sem pressioná-las, como num glissando ${ }^{8}$.

8 Um efeito semelhante a este é utilizado pelo compositor na obra Paná-Paná II, na parte do violoncelo, onde também está associado a arpejos rápidos no registro agudo do piano (BARANCOSKI, 2005). Também ocorre na obra Le Livre Magique de Xangô (SANTOS, 2017). 


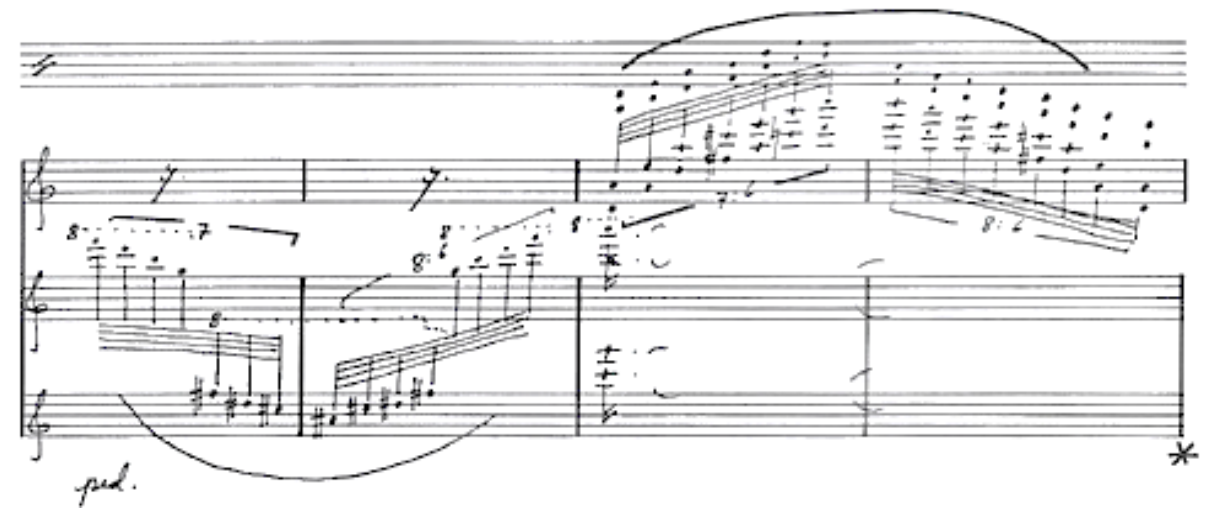

Figura 1 | - Sonata n I para violino e piano, mov. II: harmônicos

Em seguida, a combinação de trinado e glissando num mesmo gesto cria um efeito inusitado na escrita violinística. $\bigcirc$ movimento termina com uma linha ascendente do violino em harmônicos artificiais, sobreposta ao movimento descendente do piano.

Na sua natureza processual, a música vai se transformando através de uma sequência de eventos sonoros. Esses eventos são, em sua maioria, explorações timbrísticas do violino, por meio de efeitos como trêmulo sul ponticello e glissando em pizzicato, que aludem a uma sonoridade fora do comum, fantasiosa - como indica o título deste movimento. Embora em si mesmos não apresentem novidade - tais recursos já estão estabelecidos na literatura do instrumento - sua utilização num contexto contemporâneo para criação de efeitos sonoros específicos pode ser considerada como técnica expandida (COPETTI; TOKESHI, 2005). Almeida Prado viria a utilizar algumas dessas técnicas no segundo movimento, Inverno9', da sua obra As quatro estações, de 1984. Peça de caráter pedagógico, poderia funcionar como preparação técnica e musical para o estudo deste movimento.

9 subtítulo desse movimento é "Estudo de efeitos: trêmulo normal, trêmulo s.p., harmônicos". Sobre essa peça, ver Ansate (2009). 


\section{Movimento III: Com luminosidade interior}

$\bigcirc$ título deste movimento sugere introspecção e possivelmente remete à religiosidade do compositor, tema frequentemente presente em suas obras. Em forma de tema e variações, o tema é apresentado exclusivamente pelo piano, permeado por harmonias transtonais e pela insistência no gesto de colcheia e semínima pontuada entre as notas Lá e Si. Esta figura, quando tocada com um certo impulso na colcheia, isto é, tornando-a mais pesada e articulada com maior velocidade do arco, e repousando na semínima pontuada, com menor velocidade do arco, direciona e dá unidade a todo este movimento. A repetição de acordes emula as badaladas de um sino que ecoa ao longo de todas as variações.

Na primeira variação, a melodia do violino apresenta grandes saltos intervalares (Figura 12). $\bigcirc$ espaçamento entre as notas explora a diversidade de registros do instrumento e sugere uma movimentação tanto horizontal quanto vertical de ocupação do espaço sonoro, criando uma sonoridade bidimensional tênue, esparsa e difusa, condizente com a indicação Translúcido!! ${ }^{10}$ Do ponto de vista da execução, a ampliação intervalar traz a complexidade de mudanças de cordas frequentes e o desafio de conectar o final de uma nota ao início da próxima ao direcionar a frase musical. A experiência de tocar uma versão da melodia com intervalos invertidos, isto é, uma $2^{a}$ maior descendente ao invés de $7^{\square}$ menor ascendente, por exemplo, permite uma escuta mais concentrada e uma compreensão concisa da frase musical (Figura 13).

10 Concorre, ainda, para criar este efeito translucente o fato de o violino iniciar esta variação desacompanhado, desenvolvendo sua linha melódica sobreposta apenas à ressonância do último acorde do tema. 


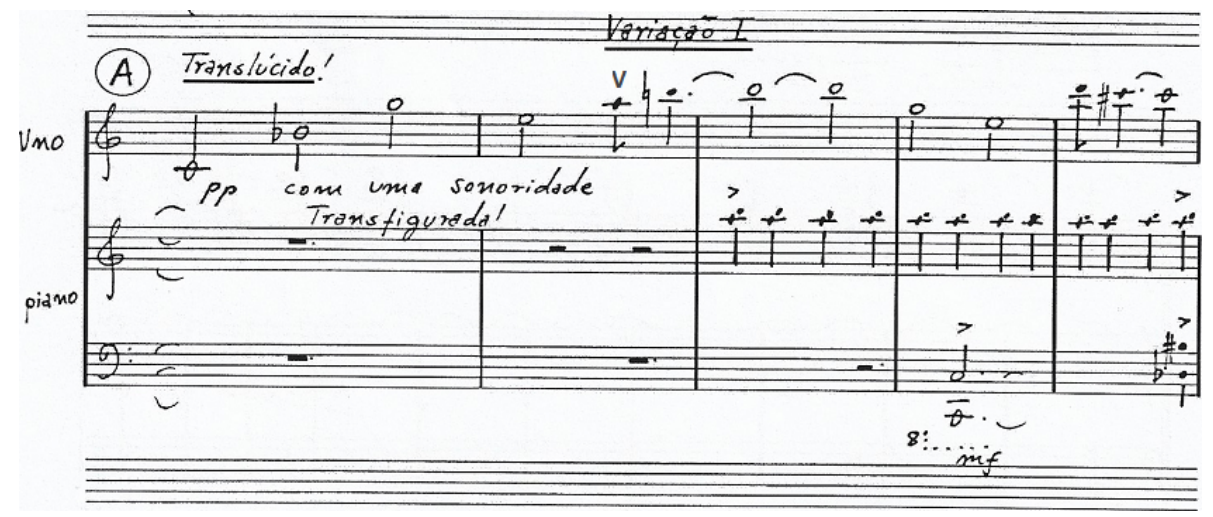

Figura 12 - Sonata $n^{\circ}$ | para violino e piano, mov. III: variação |

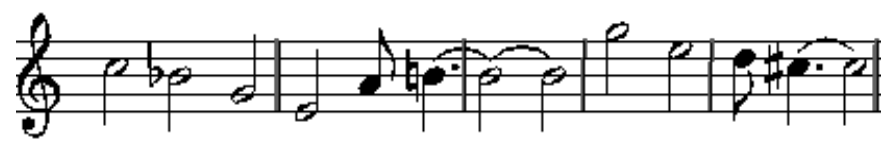

Figura 13 - Simplificação intervalar

Na variação II, a indicação suavíssimo não se refere apenas à intensidade do som - fosse este o caso, uma indicação de dinâmica como pianíssimo bastaria -, mas trata-se do caráter e do contato do arco com a corda que o intérprete utiliza para reproduzir, ao tocar, o gesto delicado, com ataque macio e pouco articulado que a metáfora implica. Mais uma vez, a metáfora parece ser determinante para a execução musical.

No final desta variação, o violino toca harmônicos em cordas duplas que reproduzem a sonoridade de sinos e que funcionam como elemento de ligação para a variação seguinte. Ao imitar a execução do piano nesses acordes, no qual há um decaimento do som após o ataque, busca-se uma articulação com uma breve separação entre as notas. A sensação do movimento de pêndulo no braço favorece a uniformidade sonora dessas notas. 
No início da Variação III, a movimentação das figuras arpejada do piano contrasta com a estaticidade da variação anterior e cria sonoramente a atmosfera surreal indicada por "Como um sonho" (Figura 14). No violino, esta sonoridade onírica é elaborada através de efeitos de harmônicos naturais e artificias e também pelo uso do arco sobre o cavalete, isto é, sul ponticello. Nesta variação, os acordes repetidos aparecem interpolados à figuração arpejada do piano, revelando uma maior integração do material temático ${ }^{11}$.

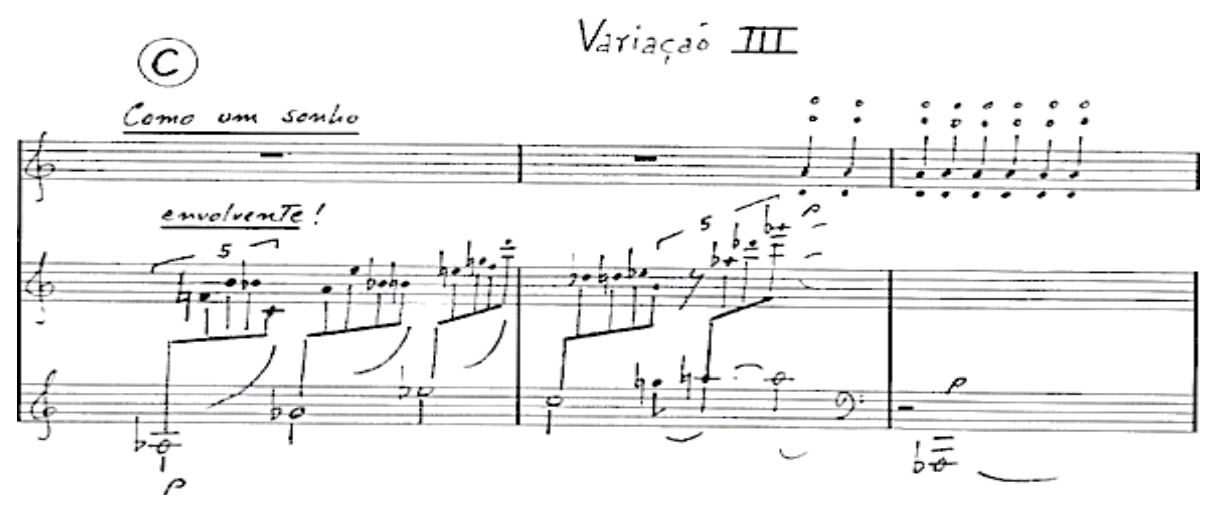

Figura 14 - Sonata nº | para violino e piano, mov. |||: variação |||

A narrativa musical de caráter velado e intimista, criada através de dinâmicas suaves, é abruptamente interrompida por um cluster em fortíssimo no registro grave do piano, o que dá início à quarta variação (Figura 15). A sonoridade densa e dramática desta variação, indicada por Súbito, intenso!, opõe-se à textura rarefeita desenvolvida anteriormente. A intensidade expressiva fica evidente não só pelo maior volume sonoro, mas também pela expansão rítmica e intervalar - o gesto rítmico de colcheia seguida por semínima pontuada se transforma em tercina e, melodicamente, o intervalo de $2^{\circ}$ é ampliado para uma $7^{\circ}$ menor ascendente -, cuja execução implica em movimentos de maior amplitude, tanto na mão esquerda quanto no arco.

1 No tema e na segunda variação, esses acordes aparecem na conclusão da frase musical e constituem um elemento transicional para a seção seguinte. 


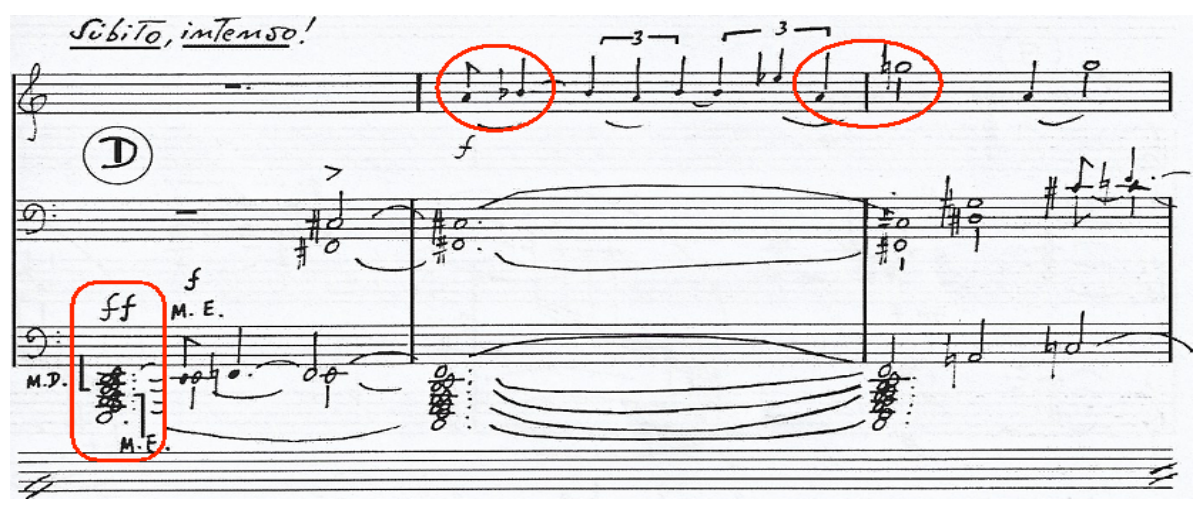

Figura 15 - Sonata $n^{\circ}$ | para violino e piano, mov. III: variação IV

Na última variação (V), a dinâmica volta a ser piano, mas a sonoridade é aberta e luminosa, como um insight que ilumina o caminho para a resolução da tensão, conforme a indicação "como uma revelação". Essa luminosidade e clareza é traduzida sonoramente pelos arpejos do piano, num gesto rápido e reluzente na região mais aguda e brilhante do instrumento. $\bigcirc$ gesto ascendente do violino que culmina com a figura motívica (colcheia seguida por semínima pontuada) acentua a luminescência da frase (Figura 16). 


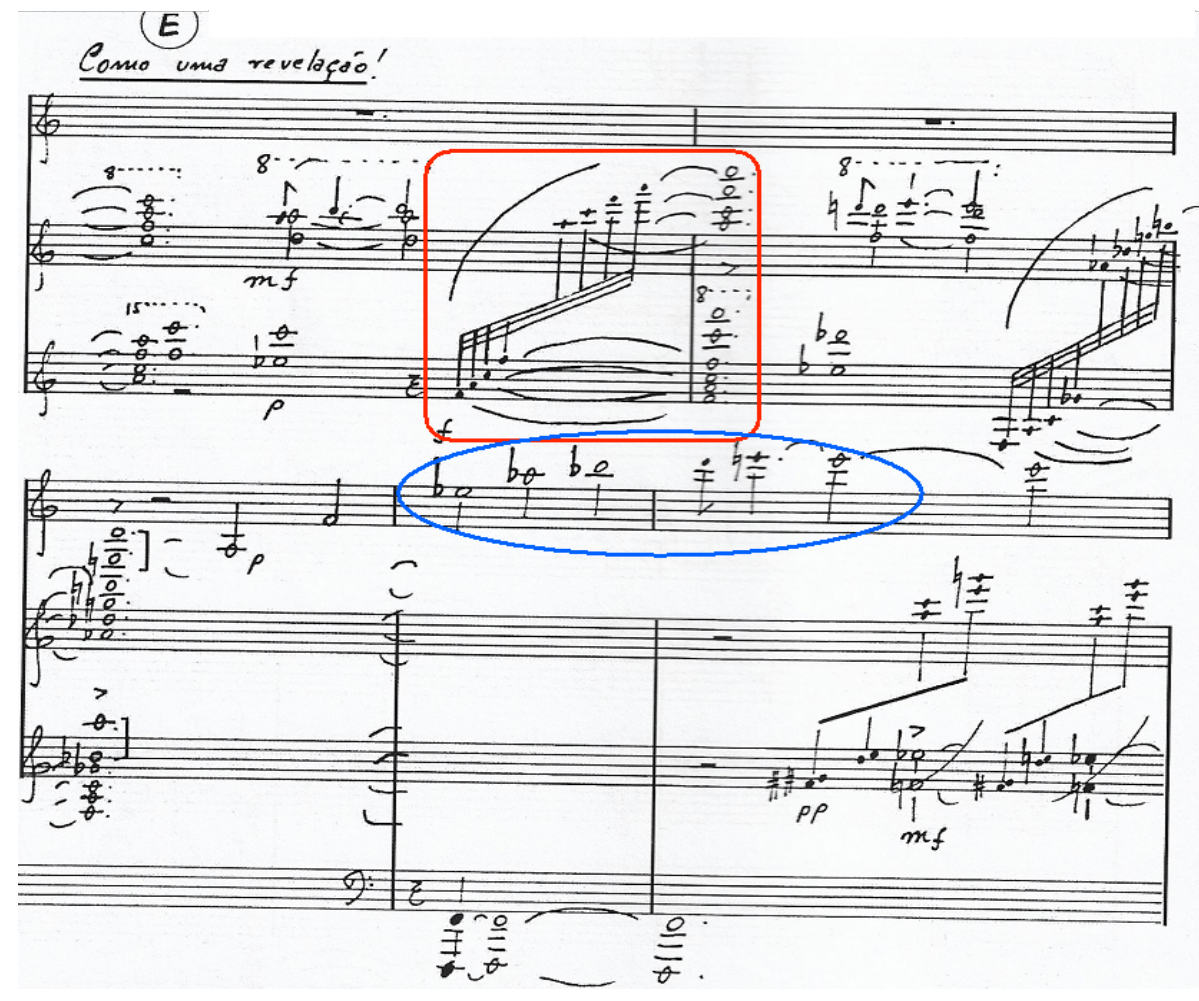

Figura 16 - Sonata $n^{\circ}$ I para violino e piano, mov. III: variação V

A exploração de diversas ambientações sonoras é concluida com o retorno da textura harmônica do tema inicial, que encerra o ciclo das variações.

\section{Movimento IV: Movimento contínuo e acelerante}

Atemático e rítmico, este movimento de caráter agitado, quase frenético, inicia-se com trêmulo em sul ponticello no violino, criando uma aura nervosa, tensa e de suspense. A entrada do piano introduz a quiáltera de três semínimas no compasso binário e estabelece uma nova sensação de pulso, mais rápido, que é imediatamente transformado na nova unidade de tempo, através da modulação métrica. Com 
este procedimento, que consiste na "modificação gradual das figuras rítmicas básicas responsáveis pela sensação das unidades de tempo, proporcionando [a sensação de] uma nova unidade de tempo, [...] consegue-se mudanças de andamento de forma gradual e orgânica" (RODRICUES, 2006, p. 49). É o principal fundamento sobre o qual este movimento é construido, pois é através dele que se cria tensão, continuidade e direcionalidade, ao estabelecer um accelerando gradativo ao longo da obra. A modulação métrica injeta fluidez e flexibilidade neste Finale - movimento que tradicionalmente está associado à consistência rítmica e à estabilidade do pulso (ROSEN, 1988).

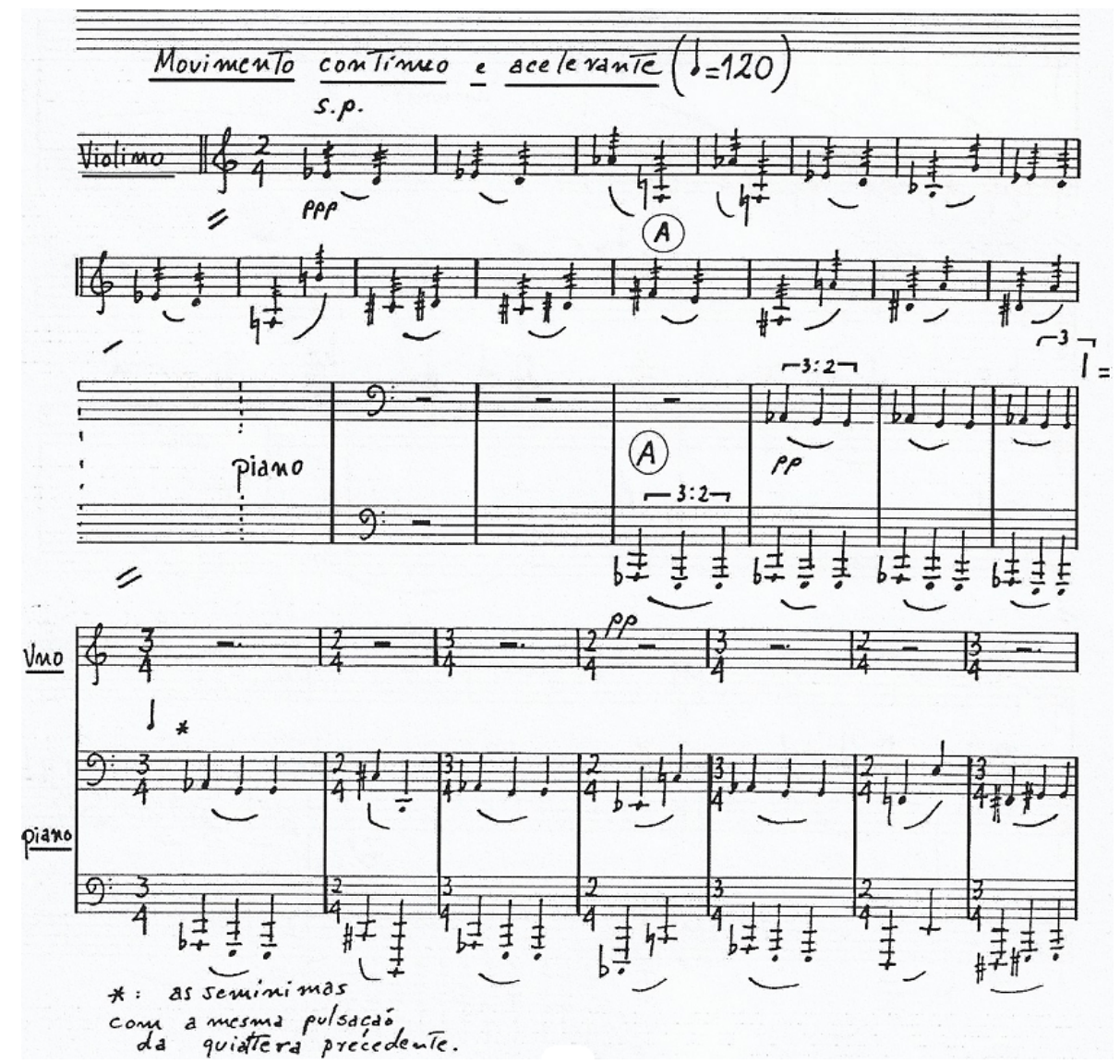

Figura 17 - Sonata $n^{\circ}$ I para violino e piano, mov. IV: c. $1-22$ 
A alternância métrica entre compassos $3 / 4$ e 2/4 (Figura 24) é reelaborada posteriormente na subdivisão binária e ternária do pulso dentro do compasso 5/8 (Figura 19). É um elemento rítmico cuja origem provém de um desdobramento do material temático do primeiro movimento (Figura 18).

(113)

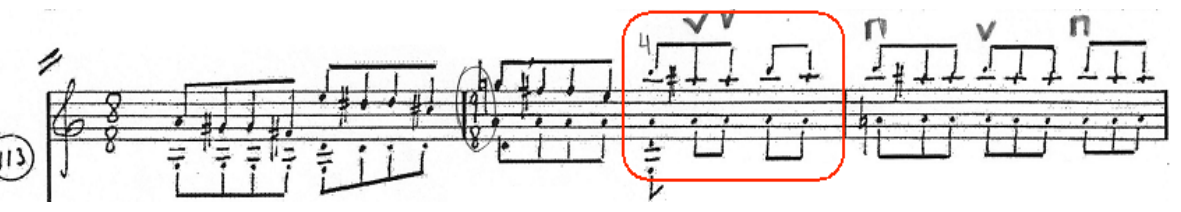

Figura 18 - Sonata $n^{\circ}$ | para violino e piano, mov. I: c. 113-115

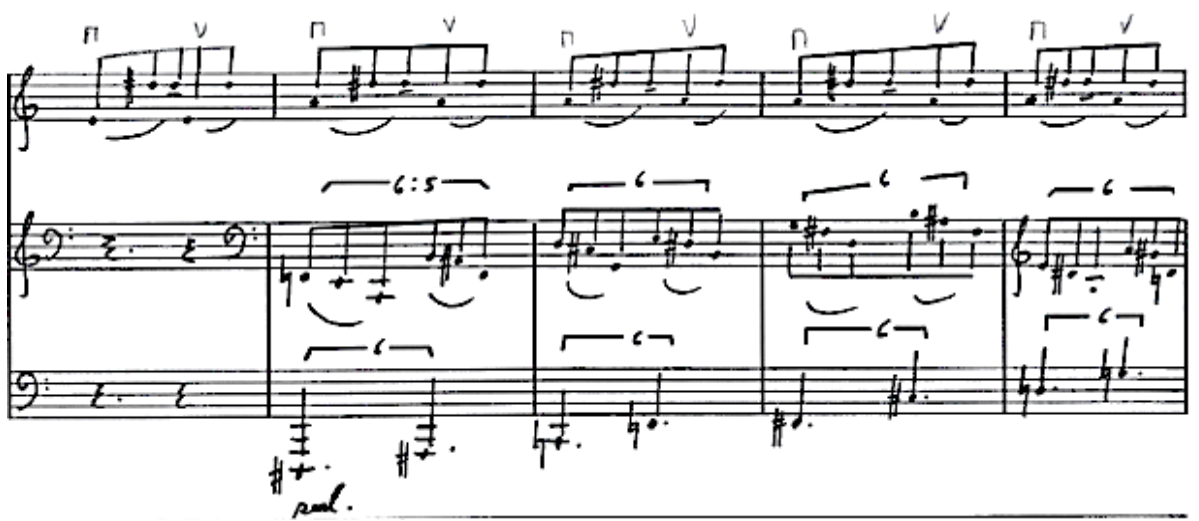

Figura 19 - Sonata $\mathrm{n}^{\circ}$ I para violino e piano, mov. IV: [E]

A repetição contínua desse gesto rítmico remete ao ostinato ritualístico que o compositor exploraria amplamente nas obras Le Livre Magique de Xangô e na Sonata n 5 "Omulú" (1985). A arcada sugerida segue a indicação das ligaduras e permite uma execução consistente da mesma arcada em todos os compassos (Figura 26). Outra possibilidade seria desligar a terceira colcheia, o que levaria a uma execução mais articulada e com arcadas alternadas, isto é, um compasso começaria para baixo e o seguinte seria para cima. A sextina do piano acrescenta polirritmia adensa à textura musical e prepara a modulação métrica para 6/8.

As modulações métricas criam um gesto contínuo de aceleração em direção ao final da obra. A linha ascendente dos instrumentos culmina no cluster de teclas pretas e brancas no registro extremo-agudo do 
piano que encerra a obra. As notas Fá sustenido e Si nos extremos deste bloco sonoro maciço retomam a polarização em Si estabelecida no tema inicial da obra, num gesto conclusivo reminiscente das relações tonais da forma sonata tradicional.

\section{Considerações finais}

Escrita em 1980, a primeira sonata encontra-se ainda sob o vigor moderno experimental, da busca pelo novo, de ampliar as possibilidades sonoras da combinação violino-piano ao explorar a fusão timbrística dos instrumentos. Dedicada ao virtuose Natan Schwartzman, não se impõem limites de dificuldades técnicas, explorando com liberdade diversos recursos expressivos do violino. Efeitos como glissandi de harmônicos em cordas duplas e trêmulo sul ponticello, interpolados a recursos composicionais diversos como transtonalismo, serialismo e modulação métrica, constituem um discurso complexo - elaborado ora através de um diálogo entre os instrumentos, ora pela sua sobreposição - cuja inteligibilidade é garantida pela estruturação formal clara, que revela um domínio absoluto do metier. A grande diversidade de materiais sonoros e as sugestivas indicações metafóricas são um convite para a exploração das possibilidades timbrísticas do piano e do violino.

A estratificação da sonoridade em diversos planos amplia a ocupação do espaço sonoro e possibilita uma simultaneidade de eventos que constroem os diversos blocos sonoros da obra. Enquanto as ressonâncias do piano são exploradas por meio de clusters, arpejos rápidos e repetição de ostinatos, no violino, o uso das cordas soltas em acordes e arpejos - o que resulta na vibração dessas cordas por mais tempo, criando um efeito de ressonância semelhante ao produzido pela suspensão dos abafadores pelo acionamento do pedal direito do piano - revela a preocupação e a criatividade do compositor ao utilizar recursos de maior ressonância nesse instrumento.

Nessa obra, Almeida Prado privilegia o aspecto lírico do violino e sua capacidade de sustentação sonora, criando longas linhas melódicas em legato sobre a linha mais movimentada do piano. No piano, o som tende a se extinguir logo após o ataque e através do uso do pedal pode-se criar a ilusão do legato. Tendo em vista que nos instrumentos de cordas esse efeito é produzido com certa facilidade,

\section{3}

REV. TULHA, RIBEIRÃO PRETO, v. 5, n. 1, pp. 87-118, jan.-jun. 2019 
o compositor explora amplamente este recurso sonoro na elaboração textural.

Na Sonata $n^{\circ}$ 1, a linguagem musical não se submete às restrições da notação nem sacrifica a espontaneidade do gesto criativo ao transcrevê-lo, revelando a proeminência do timbre na elaboração das concepções musicais do compositor. Afinal, Segundo o próprio Almeida Prado: "sou um compositor tímbrico. Você não pode tocar minha música sem pensar no timbre, sem procurar efeitos de ataque [...]. Você tem realmente que pesquisar, porque não está na partitura" (MOREIRA, 2002, p. 76). Nesta busca pelo som reside o maior trabalho investigativo do performer, pois "[o] timbre está diretamente relacionado com o ato interpretativo e, ao tomar consciência disto, o intérprete se sentirá como um pesquisador das potencialidades sonoras de seu instrumento e de si próprio, desenvolvendo assim a sua escuta e consequentemente, uma performance mais sensivel" (ASSIS, 1997, p. 2).

Sua escrita musical não é prescritiva, dando liberdade ao intérprete para decidir acerca das especificidades pontuais de dinâmica e articulação - indicando apenas num âmbito geral as intenções do compositor. As indicações metafóricas se tornam um importante veículo de comunicação, transmitindo peculiaridades de um imaginário sonoro que transcende a notação musical. Para Almeida Prado, a metáfora serve um recurso expressivo que desperta a imaginação do intérprete para além do que vê e do que ouve na partitura. Não é uma descrição precisa da imagem sonora, mas sugestiva de sensações físicas que o intérprete incorpora nos seus gestos geradores de som. Ao utilizá-la, o compositor coloca-se lado a lado ao intérprete na formulação da sua interpretação da obra, numa linguagem que the é tão familiar: a da metáfora.

Na primeira sonata, a metáfora aparece de forma inerente à execução musical, tanto nos movimentos que o intérprete realiza para tocar quanto na sensação física que se percebe no contato com o instrumento. A indicação Granítico no primeiro movimento está atrelada ao gesto físico de tocar o material temático em fortíssimo, com acentos, no registro mais grave do instrumento, produzindo um som metaforicamente "denso", "pesado" e "frio". O peso e a dureza do granito se tornam concretos no contato do arco com a corda que, por ser a mais grave e mais espessa, apresenta maior inércia e requer o uso de maior peso do braço. Como cristais transparentes retrata a fragilidade do material e a

\section{4}

REV. TULHA, RIBEIRÃO PRETO, v. 5, n. 1, pp. 87-118, jan.-jun. 2019 
delicadeza no seu manuseio, caracterizando a natureza do contato do arco com a corda nessa seção da obra - leve e delicado, sugerindo um movimento de retirar peso do arco.

Segundo Cox (201 1), a metáfora provoca uma sensação física que modifica a qualidade do movimento corporal empregado ao tocar $e_{\text {, }}$ portanto, do resultado sonoro. Assim, a metáfora, ao revelar a inspiração criativa do compositor e estimular o imaginário do intérprete, instiga a busca por uma variedade de timbres que enriquece a performance e a paleta sonora do instrumentista. Enquanto recurso expressivo, transcende os limites da notação musical e torna-se um elemento fundamental para - processo de elaboração interpretativa da primeira sonata para violino e piano de Almeida Prado.

\section{Referências}

ALMEIDA PRADO, José Antônio Rezende de. Sonata no I para violino e piano. Campinas, 1981 . Violino e piano. ms.

ALMEIDA PRADO, José Antônio Rezende de. Música Contemporânea Brasileira. Constança de Almeida Prado, violino; Achile Picchi e Helenice Audi, piano. Centro Cultural São Paulo. São Paulo: Discoteca Oneyda Alvarenga, c2006. 110 f. + I CD + I partitura.

ANSATE, Walter F. As quatro estações para violino solo de Almeida Prado. 2009. Dissertação (Mestrado em Música), Instituto de Artes, Universidade Estadual de Campinas, Campinas, 2009.

ASSIS, Ana Cláudia de. O timbre de llhas e Savanas de Almeida Prado - uma contribuição às práticas interpretativas. 1997. Dissertação (Mestrado em Música). Universidade do Rio de Janeiro, Rio de Janeiro, 1997.

BARANCOSKI, Ingrid. "A música de câmara de Almeida Prado". Revista Brasiliana, n. 21, p. 12-18, 2005.

BITTENCOURT, Maria Cristina F. "Algumas palavras sobre metáfora e interpretação musical". Em pauta, Porto Alegre, v. 19, n. 32/33, p. 76-99, jan./dez. 2008. 
BORÉM, Fausto; RAY, Sônia. Pesquisa em performance musical no Brasil no século XXI: problemas, tendências e alternativas. In: II SIMPÓSIO BRASILEIRO DE PÓS-CRADUANDOS EM MÚSICA, 2012. Anais... Rio de Janeiro, 2012. p.122-168.

COOK, Nicholas. Beyond the score: music as performance. Oxford: Oxford University Press, 2013.

COPETTI, Rafaela; TOKESHI, Eliane. A técnica expandida para violino: classificação e avaliação de seu emprego na música brasileira. In: XV ENCONTRO DA ASSOCIAÇÃO NACIONAL DE PESQUISA E PÓS GRADUAÇÃO EM MÚSICA, 2005, Rio de Janeiro. Anais... Rio de Janeiro: ANPPOM, 2005. p. $318-323$.

CORREIA, Jorge S. "Um modelo explicativo do trabalho do intérprete". In: MONTEIRO, F.; MARTICO, A. (Ed.). Interpretação Musical: Teoria e Praxis. Lisboa: Colibri, 2007. p. 63-107.

CORVISIER, Fernando. The ten piano sonatas of Almeida Prado: the development of his compositional style. 2000. Tese (Doutorado em Música), University of Houston, Houston, 2000.

CORVISIER, Fernando. A voz do performer: considerações interpretativas nos Noturnos para piano de Almeida Prado. 2017. Tese (Livre docência), Universidade de São Paulo, São Paulo, 2017.

COX, Arnie. "Embodying music: principles of the mimetic hypothesis". Music theory online, v. 17, n. 2, July 2011. Disponivel em: http://www.mtosmt. org/issues/mto.11.17.2/mto.11.17.2.cox.html. Acesso em: 19 jun. 2017.

DAVIDSON, Jane. "Practice-based music research: lessons from a researcher's personal history". In: DOĞANTAN-DACK, M. Artistic practice as research in music. New York: Ashgate, 2015. p. 93-106.

DOC̆ANTAN-DACK, Mine. "In the beginning was gesture: piano touch and the phenomenology of the performing body". In: CRITTEN, A; KINC, E. (Ed.). New perspectives on music and gesture. Burlington, VT: Ashgate, 2011. p. 243-265.

DOC̆ANTAN-DACK, Mine. "The role of the musical instrument in performance as research: the piano as a research tool". In: 
DOC̆ANTAN-DACK, Mine. (Ed.). Artistic practice as research in music. New York: Ashgate, 2015. p.169-202.

FERRAZ, Maria H. An overview of Almeida Prado's "Transtonal" System in his Cartas

Celestes, first six volumes, for piano solo. 2009. Tese (Doutorado em Música), The University of Arizona, Tucson, 2009. Disponivel em: http:// arizona.openrepository.com/arizona/handle/10150/194305. Acesso em: 23 jun. 2017.

FERREIRA, Aurélio B.H. Novo Dicionário Aurélio. 2 ed. Rio de Janeiro: Nova Fronteira, 1986.

CANDELMAN, Salomea; COHEN, Sara. Cartilha ritmica para piano de Almeida Prado. Rio de Janeiro, 2006.

LEECH-UILKINSON, Daniel; PRIOR, Helen. "Heuristics for expressive performance". In: FABIAN, D. et all. (Ed.). Expressiveness in music performance: empirical approaches across styles and cultures. Oxford: Oxford University Press, 2014. p. 34-57.

MARIZ, Vasco. História da Música no Brasil. 4 ed. Rio de Janeiro: Civilização Brasileira, 1994.

MOREIRA, Adriana Lopes da Cunha. A poética nos 16 Poesilúdios para piano de Almeida Prado: Análise musical. 2002. Dissertação (Mestrado em Música). Instituto de Artes, Universidade Estadual de Campinas, Campinas, 2002.

NIETO, Albert. El gesto expressivo del pianista. Barcelona: Editorial de Música Boileal, 2016.

RINK, John. "The work of the performer". In: DE ASSIS, Paulo. Virtual works, actual things: essays in musical ontology. Leuven: Leuven University Press, 2018 . p. 89- 114.

RODRICUES, Lutero. "As obras para violino e piano de Almeida Prado". In: ALMEIDA PRADO, José António Rezende de. Música Brasileira Contemporânea. Constança de Almeida Prado (violino), Achile Picchi e 
Helenice Audi (piano). São Paulo: Centro Cultural São Paulo, 2006. 110 f. + I CD + I partitura.

ROSEN, Charles. Sonata forms. Nova lorque: W. W. Norton \& Company, 1988.

SANTOS, Eduardo Luiz Bello dos. Considerações interpretativas da obra Le Livre Magique de Xangô de Almeida Prado. 2017 . Dissertação (Mestrado em Música), Escola de Comunicações e Artes, Universidade de São Paulo, São Paulo, 2017.

\section{Sobre os autores}

Luciana Caixeta é bacharel em música pela Universidade de São Paulo e mestre em performance pela Miami University. Desenvolveu extensa atividade como camerista e musicista de orquestra. Atuou como chefe de naipe da Hamilton-Fairfield Symphony, Lebanon Symphony, Middletown Symphony e da Orquestra Filarmônica de São Carlos. Foi docente das disciplinas de violino e música de câmara junto ao Departamento de Música da FFCL/RP da Universidade de São Paulo. Atualmente é professora da Escola de Música de Brasília e doutoranda em música pela Escola de Comunicações e Artes da Universidade de São Paulo, desenvolvendo pesquisa sobre as sonatas para violino e piano de Almeida Prado.

Fernando Corvisier aperfeiçoou-se no exterior na Ecole Normale de Musique Alfred Cortot em Paris, no New England Conservatory em Boston, na Hartt School of Music e obteve o título de doutor pela Universidade de Houston. Vencedor do IV Prêmio Eldorado de Música, gravou com o pianista João Carlos Martins a transcrição de Almeida Prado para dois pianos das Quatro Estações de Vivaldi. Gravou para o selo Eldorado obras de Brahms e Cinastera. Recentemente, gravou a integral dos Noturnos para Piano do compositor Almeida Prado. Participou de diversos festivais de música no Brasil e exterior como docente e recitalista. Desde 2002, é docente de piano do Departamento de Música da FFCLRP-USP.

Recebido em 23/05/2019

Aprovado em 31/07/2019 